\title{
Why is ALS so Difficult to Treat?
}

\author{
John Turnbull
}

\begin{abstract}
Amyotrophic lateral sclerosis (ALS) is proving intractable. Difficulties in pre-clinical studies contribute in small measure to this futility, but the chief reason for failure is an inadequate understanding of disease pathogenesis. Many acquired and inherited processes have been advanced as potential causes of ALS but, while they may predispose to disease, it seems increasingly likely that none leads directly to ALS. Rather, two recent overlapping considerations, both involving aberrant protein homeostasis, may provide a better explanation for a common disease phenotype and a common terminal pathogenesis. If so, therapeutic approaches will need to be altered and carefully nuanced, since protein homeostasis is essential and highly conserved. Nonetheless, these considerations provide new optimism in a difficult disease which has hitherto defied treatment.
\end{abstract}

RÉSUMÉ: Pourquoi la SLA est-elle si difficile à traiter? : La sclérose latérale amyotrophique (SLA) s'avère impossible à traiter. Les difficultés rencontrées dans les études précliniques contribuent en partie à cet insuccès. Mais la principale raison d'échec est liée au fait que la pathogenèse de la maladie demeure mal comprise. Plusieurs mécanismes acquis ou héréditaires ont été proposés comme causes potentielles de la SLA, mais bien qu'ils puissent conférer une prédisposition à la maladie, il semble de plus en plus plausible qu'aucun ne mène directement à la SLA. Il semble plutôt que deux théories qui se chevauchent, qui toutes deux impliquent une homéostasie protéique aberrante, pourraient mieux expliquer l'observation d'un phénotype commun associé à une pathogenèse de base qui serait commune. Si c'est le cas, les approches thérapeutiques devront être modifiées et nuancées avec précaution parce que l'homéostasie protéique est essentielle et hautement conservée. Néanmoins, ces considérations fournissent un nouvel optimisme face à une maladie pénible qui est demeurée intraitable jusqu'ici.

Can J Neurol Sci. 2014; 41: 144-155

No neurodegenerative disease is well treated, but Amyotrophic lateral sclerosis (ALS) is proving particularly intractable. To date, 53 of 54 potential treatments tested in human trials (Table 1) $)^{1-57}$ have failed and the sole successful agent (riluzole) is supported by evidence so muted that false positive results due to chance cannot be completely excluded. Indeed it is likely that additional failed trials have gone unreported. The following discussion, hypothetical by nature, sets out possible reasons why therapeutic success has been elusive to date, outlines two recent directions that may be important in our understanding of ALS, and suggests reasons why future treatment may continue to be challenging.

\section{A. Why has therapeutic success been so difficult to date?}

\section{ALS is a complex disease with genetic and environmental components}

First, ALS has been difficult to conceptualize and treat because important aspects are incompletely understood. Sporadic and multiple familial forms are recognized that are clinically indistinguishable $\mathrm{e}^{58}$, but we do not understand the explanation for the common disease phenotype. The only predisposing factor of major significance is age, for reasons that also remain unclear.
Multiple cell types are involved, with genetic, environmental, and possibly stochastic influences at play. The chief features of ALS relate to motor neuron involvement with variable frontotemporal dementia, but multiple cell types modify disease expression. In transgenic mice over-expressing a human mutant SOD1 (mSOD), the first-described cause of familial ALS ${ }^{59}$ (FALS), restricting expression of $\mathrm{mSOD}$ to motor neurons alone may or may not result in any clinical disease ${ }^{60-62}$, and the disease is modified by transgene expression in microglia ${ }^{63}$, oligodendroglia $^{64}$, astroglia ${ }^{65}$, Schwann cells ${ }^{66,67}$, and skeletal muscle $^{68}$. Even within the same cell type, there is important heterogeneity ${ }^{69,70}$.

Twin studies in sporadic ALS have identified the likelihood of genetic and environmental influences, perhaps of about equal magnitude ${ }^{71}$. Environmental influences could include neurotrophic viral infection, neurotoxins, and nervous system trauma,

From the Department of Medicine, McMaster University, Hamilton, Ontario, Canada. Received September 12, 2013. Final Revisions Submitted September 16, 2013. Correspondence to: John Turnbull, Andrew Bruce Douglas Chair of Neurology, Department of Medicine, McMaster University, 1200 Main St W, Hamilton Ontario, L8N 3Z5, Canada. Email: turnbull@mcmaster.ca. 
Table 1: Agents studied in human ALS trials

\begin{tabular}{|c|c|c|c|}
\hline Agent & Rationale & Result & Reference \\
\hline TCH 346 & Anti-apoptotic & negative & {$[1]$} \\
\hline Physostigmine & Anti-cholinergic & negative & {$[2]$} \\
\hline Tet hydroaminoacridine & Anti-cholinergic & negative & [3] \\
\hline Branched chain AAs & Anti-excitotoxic & negative & [4] \\
\hline Ceftriaxone & Anti-excitotoxic & negative & {$[5]$} \\
\hline Dextromethorphan & Anti-excitotoxic & negative & [6] \\
\hline Gabapentin & Anti-excitotoxic & negative & [7] \\
\hline Lamotrogine & Anti-excitotoxic & negative & [8] \\
\hline L Threonine & Anti-excitotoxic & negative & [9] \\
\hline Memantine & Anti-excitotoxic & negative & {$[10]$} \\
\hline Nimodipine & Anti-excitotoxic & negative & {$[11]$} \\
\hline Talampanel & Anti-excitotoxic & negative & {$[12]$} \\
\hline Topiramate & Anti-excitotoxic & negative & [13] \\
\hline Transcranial stim. & Anti-excitotoxic & negative & {$[14]$} \\
\hline Verapamil & Anti-excitotoxic & negative & {$[15]$} \\
\hline Riluzole & Anti-excitotoxic? & positive & {$[16]$} \\
\hline Valproic Acid & Anti-excitotoxic.... & negative & {$[17]$} \\
\hline Azothiaprine & Anti-inflammatory & negative & {$[18]$} \\
\hline Celecoxib & Anti-inflammatory & negative & [19] \\
\hline Cyclophosphamide & Anti-inflammatory & negative & {$[20]$} \\
\hline Cyclosporine & Anti-inflammatory & negative & [21] \\
\hline Glatiramer Acetate & Anti-inflammatory & negative & {$[22]$} \\
\hline Interferon alpha & Anti-inflammatory & negative & [23] \\
\hline Interferon beta & Anti-inflammatory & negative & [24] \\
\hline IvIg & Anti-inflammatory & negative & [25] \\
\hline Minocycline & Anti-inflammatory & negative & [26] \\
\hline Pentoxyfilline & Anti-inflammatory & negative & [27] \\
\hline Snake Venom & Anti-inflammatory & negative & [28] \\
\hline Total lymph radiation & Anti-inflammatory & negative & [29] \\
\hline Edaravone & Anti-oxidant & negative & {$[30]$} \\
\hline Glutathione & Anti-oxidant & negative & [31] \\
\hline n-Acetyl Cysteine & Anti-oxidant & negative & {$[32]$} \\
\hline Selegiline & Anti-oxidant & negative & [33] \\
\hline Vitamin E & Anti-oxidant & negative & [34] \\
\hline Selegeline + Vitamin E & Anti-oxidant & negative & {$[35]$} \\
\hline Amantadine / guanidine & Anti-viral & negative & {$[36]$} \\
\hline Guanidine & Anti-viral & negative & [37] \\
\hline Indivavir & Anti-viral & negative & {$[38]$} \\
\hline Isoprinosine & Anti-viral & negative & [39] \\
\hline Tilorone & Anti-viral & negative & [40] \\
\hline Lithium & Autophagy / mitochondrial & negative & {$[41,42]$} \\
\hline Transfer factor & Immunomodulator & negative & {$[43]$} \\
\hline CoEnzyme Q10 & Mitochondrial & negative & [44] \\
\hline Creatine & Mitochondrial & negative & [45] \\
\hline Dexpramipexole & Mitochondrial & negative & [46] \\
\hline Olesoxime & Mitochondrial & negative & {$[47]$} \\
\hline BDNF & Neurotrophic & negative & [48] \\
\hline Ganglioside & Neurotrophic & negative & {$[49,50]$} \\
\hline Growth Hormone & Neurotrophic & negative & {$[51,52]$} \\
\hline Insulin-like GF (IGF) & Neurotrophic & negative & {$[53]$} \\
\hline Xaliproden & Neurotrophic & negative & {$[54]$} \\
\hline CNTF & Neurotrophic & negative & {$[55]$} \\
\hline TRH & Neurotrophic? & negative & {$[56]$} \\
\hline 3,4 Diaminopyridine & transmitter release & negative & {$[57]$} \\
\hline
\end{tabular}

as set out later. There may be a genetic/environmental interaction in ALS that obscures epidemiological attempts to identify these components separately, and further complicates an already difficult disease.

In highly inbred transgenic mSOD mice, there is still variability in disease onset that might reflect differences in unrecognized genetic modifiers or, perhaps just as likely, reflect the play of chance.

\section{Preclinical studies are problematic}

Nearly all agents that have failed in recent human trials have been supported by positive preclinical studies in transgenic mice over-expressing a human mutant SOD1. It is possible that mSOD mice imperfectly model sporadic and most familial ALS except mSOD FALS, and even here, animal models may imperfectly mirror neurodegenerative disease in humans where the regenerative capacity of the central nervous system (CNS) is so limited. 
In mouse studies the experimental agent can be (and usually has been) administered before disease onset which may be more applicable to disease prevention rather than treatment, as discussed below. Also, transgenic ALS mice are more homogeneous than humans, in whom the cause of disease is mostly unknown and the onset and progression highly variable. It can be difficult to extrapolate an optimized dose from mouse to man, and in animals it is easier to establish effective tissue delivery and biological effect at a cellular level (of relevance to failed agents with a tight therapeutic window such as lithium, and growth factors).

However, in spite of all these caveats the positive preclinical results seen in ALS mice have generally been modest for all agents studied, and indeed, usually negative when repeated using more stringent experimental conditions ${ }^{72}$.

Thus, it is possible that larger human trials in more selected patients might have shown some benefit, and it is possible that undue reliance on preclinical models may have led to the unwarranted testing of some agents in humans. However, the reasons for failure of ALS therapy in humans run far deeper than either of these possibilities.

\section{ALS has a focal onset and spreads within the neuraxis}

Amyotrophic lateral sclerosis is usually characterized by a distinct topographical spread within the nervous system ${ }^{73}$, with some areas of the neuraxis uninvolved when other areas are diseased. Perturbation of those diverse balances- excitatory and inhibitory, pro- and anti-inflammatory, pro- and anti-apoptotic, etc, within the normal nervous system may be harmful, and treatments restoring a more beneficial balance in diseased areas risk distorting the balance in uninvolved areas.

A case in point is anti-inflammatory treatment. The symptomatic phases of ALS are accompanied by a deleterious microglial inflammatory response. However, microglia early in the ALS process in transgenic mice are neuroprotective, and only in the later stages do they accelerate neuronal death ${ }^{74}$. Antiinflammatory treatment could be beneficial in some areas of the neuraxis, neutral in some areas, and harmful in others, with an uncertain effect on the organism as a whole. This may explain, at least in part, why attempts at reducing inflammation have been unhelpful or even harmful (minocycline) in human studies.

A similar neuroprotective/neurotoxic dichotomy exists for astroglia at different stages in the illness ${ }^{75}$, with the similar conceptual concerns.

\section{Past and present approaches may be more applicable to prevention than treatment}

Multiple metabolic and genetic abnormalities potentially toxic to motor neurons have been discovered in sporadic and familial FALS, and multiple causes of disease thereby suggested. ALS is usually conceptualized as a long-standing disease resulting from progressive cellular abnormalities such as these, exacerbated in the later stages by secondary pathology such as inflammation, eventually leading to the progressive death of motor neurons. However, as set out below, neither the metabolic abnormalities nor the presently known FALS mutations may be the proximal cause of the progressive paralysis of voluntary muscle that is the hallmark of clinical disease, and treatment targeting these processes may be more suited to the prevention of ALS than its treatment.

\section{Metabolic abnormalities associated with ALS do not directly cause ALS}

Metabolic abnormalities identified in sporadic ALS include mitochondrial dysfunction, oxidative stress, inflammation, excitotoxicity, axonal impairment and trophic factor deficiency ${ }^{76}$. The treatments outlined in Table 1 are grouped by the putative disease etiology targeted, as above and, for nearly every rationale, multiple agents have been tried in well conducted human trials, some several times each, and all have failed. One can only assume that our presumptions of causality have been overly simplistic and either these abnormalities are not amenable to standard treatment or they are not essential to the actual ALS disease process.

It might be worth pointing out that no one has reported ALS induced in normal mice by treatments disrupting any of these processes. It remains possible that a multifaceted approach (targeting several or all of these) is needed but this lacks strong animal support and has failed when tried in humans ${ }^{77}$. Many processes are under homeostatic control and, if an observed abnormality arises secondary to a more relevant abnormality elsewhere in a feedback loop, correcting the observed abnormality could be counter-productive. Attempts to control transmitter levels may be particularly subject to these effects.

\section{FALS mutations predispose to ALS but do not directly cause ALS}

We now recognize more than a dozen diverse mutations that all cause Mendelian FALS, the most relevant outlined in Table 2. However, it is clear that none of these genetic 'causes' directly causes ALS in the usual sense and, specifically, ALS does not arise as an inevitable consequence of perturbations brought about by FALS mutations. Rather, they predispose to ALS and the ALS disease process itself- the rapidly progressive weakness of voluntary muscle- is separate.

All FALS mutations produce a phenotypically similar disease, after a similar asymptomatic period averaging 40-60 years (Table 2) and, once installed, the disease caused by all mutations generally has a progression independent of the trigger $^{78}$. The gene for which we have the greatest information is mutated SOD1, and here different mutations have very different rates of progression. If $\mathrm{mSOD}$ directly led to ALS, the end result of a monotonic disease process, those particular mutations of early onset should have the most rapid progression. Figure 1 is derived using data from Cudkowicz et $a l^{79}$, to demonstrate that if anything, the opposite occurs. Much more often than chance alone would allow, some FALS patients harbour two different causative mutations, yet do not differ in disease progression from patients with a single mutation ${ }^{80}$.

Transgenic mice differing in the degree of mSOD overexpression show different ages of disease onset depending on the transgene copy number, with earlier onset seen in animals with the higher copy number ${ }^{81}$. However, the degree of overexpression plays no or little role in the progression of clinical disease, which remains relatively constant. In one study high copy SOD1 mice had clinical disease onset at 109 days and 
Table 2: Onset and onset range of most common known ALS mutations (ALS On-line genetics database, available from www.alsod.iop.kcl.ac.uk/)

\begin{tabular}{c|c|c|c}
\hline Name & Mutation & Onset (yr) & Range \\
\hline ALS 1 & Super Oxide dismutase (SOD1) & 47 & $14-79$ \\
\hline ALS 4 & Senetaxin & 18 & $1-73$ \\
\hline ALS 6 & Fused in Sarcoma (FUS / TLS) & 44 & $11-80$ \\
\hline ALS 8 & VAPB & 44 & $18-73$ \\
\hline ALS 9 & Angiogenin (ANG) & 55 & $21-83$ \\
\hline ALS 10 & Tar Binding protein 43 (TDP 43) & 54 & $30-77$ \\
\hline ALS 11 & FIG4 & 55 & $29-77$ \\
\hline ALS 12 & Optineurin (OPTN) & 51 & $24-83$ \\
\hline ALS 14 & Valsolin (VCP) & 49 & $37-53$ \\
\hline ALS 15 & Ubiquilin 2 & 41 & $16-71$ \\
\hline ALS & Dynactin & 55 & $48-64$ \\
\hline ALS & Neurofilament HC (NFH) & 60 & $46-73$ \\
\hline ALS & TAF15 & 50 & $45-55$ \\
\hline ALSFTD 2 & C09ORF72 & 57 & $?$ \\
\hline
\end{tabular}

survived 42 days from that point, while low copy number mice had clinical onset at 380 days, and survived on average 41 days $^{82}$.

In asymptomatic FALS carriers destined to develop FALS, evidence of presymptomatic disease is very difficult to demonstrate, at least by sequential motor unit counting and electromyography ${ }^{83,84}$. Generally, symptoms and signs onset roughly co-incident with the electrophysiological abnormalities, with only a slight delay due to collateral sprouting. Furthermore, most recognized FALS mutations are autosomal dominant with incomplete penetrance and, typically, $10-20 \%$ of obligate carriers remain disease-free over a normal human lifespan ${ }^{85,86}$, although the true percentage may be higher ${ }^{87}$.

Finally, in transgenic mice and rats over-expressing mSOD, it is possible to target the mutant protein for destruction, or stop expression of the mutant protein at any given age. Infusion into the cerebrospinal fluid (CSF) of anti-sense oligonucleotides targeting G93A SOD1 mRNA did not arrest disease in mSOD mice, and prolonged survival by about $8 \%{ }^{88}$. Chemically stabilized siRNA targeting mSOD1 mRNA infused into the CSF shifted the survival curve in mSOD mice, but only modestly ${ }^{89}$. Infusion of antibodies targeting the G93A SOD1 protein prolonged survival by about $4 \%^{90}$. When expression of mSOD was reversed in conditional expression models, disease progression was slowed, but all animals progressed and died nonetheless ${ }^{91}$. These results suggest that reducing or eliminating exposure to mutant $\mathrm{mSOD}$ after disease onset might slow disease progression, but either the experimental interventions were unsatisfactory or a separate and at least partially independent process had been triggered.

\section{B. ALS may be a separate process of disrupted proteostasis.}

In summary, neither neurotoxic abnormalities associated with ALS, nor presently known FALS mutations, directly cause ALS, and the major reason ALS is untreatable is that key aspects of the disease remain misunderstood. Clearly the ALS phenotype has additional and unique pathophysiologic mechanisms. Under- standing these mechanisms is no guarantee of successful treatment but, in the absence, lack of success is not surprising.

Amyotrophic lateral sclerosis may be a distinct and predominantly neuromuscular process that arises with greater probability in the presence of predisposing cellular disease (metabolic perturbation, FALS mutation, neurotropic virus, etc), and, once triggered, might be self-perpetrating and capable of spread, rapidly progressive and less dependent on the initial trigger. We need then to understand how a rapidly progressive process could arise suddenly on a background of presumed good health (in sporadic disease) or, in FALS, on the background of a genetic mutation with metabolic perturbation present since conception. There are several ways this concerning scenario might arise, and two inter-related processes seem most likely to be central. Unfortunately, both involve perturbations to the

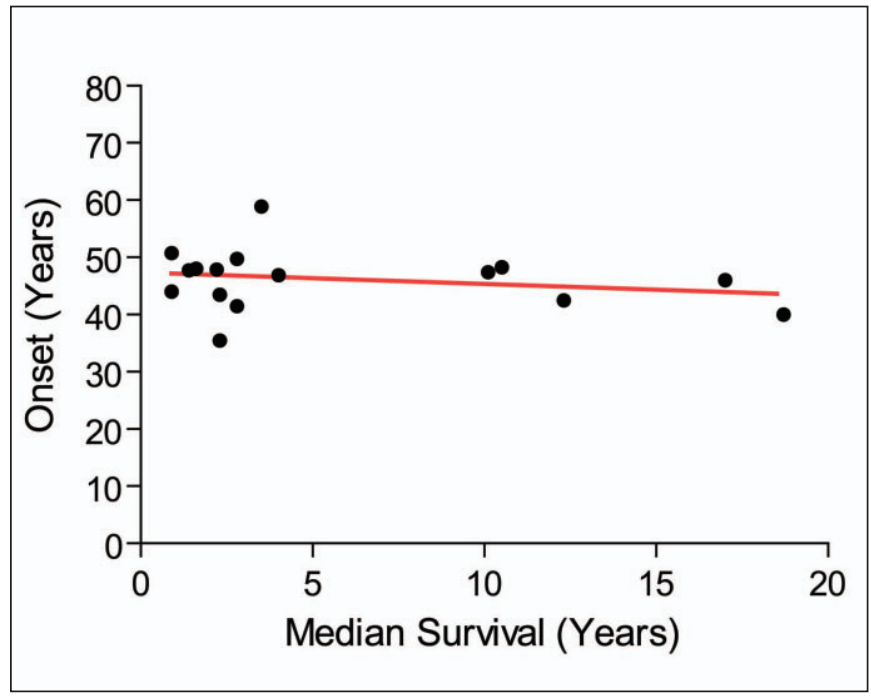

Figure 1: Onset and survival of 16 different human SOD1 mutations (after Cudkowicz ${ }^{79}$ ). 
highly conserved process of protein homeostasis ('proteostasis'), and treatment considerations may need to be considerably nuanced.

\section{i. Prion-like proteins contribute to ALS, but are linked to essential cell function}

Amyotrophic lateral sclerosis shares many features with classical prion disease and, although there is no evidence that ALS is transmissible in the usual sense ${ }^{92,93}$, abnormal proteins with prion-like qualities accumulate in ALS and in vitro can spread from cell to cell ${ }^{94,95}$. This cell-to-cell transmission is conceptually attractive as it could underlie the topographic spread of disease characteristic of many patients.

Misfolded SOD1 may behave as a self-templating protein in ALS $^{94,95}$. As would be expected, over-expression of wildtype (WT) SOD1 accelerates disease in mSOD transgenic mice ${ }^{96}$, and reducing WT SOD1 delays disease onset and slows progression in mSOD mice ${ }^{97,98}$. However, most of the conceptual interest lies in prion-like proteins involved in RNA processing.

Using bio-informatics algorithms, it is possible to predict the propensity of any protein to misfold, and of 21,873 human genes analyzed in this way, 246 were predicted to produce proteins with prion-like domains, and of these, the small group of RNA binding proteins were twelve-fold over-represented ${ }^{99}$. There are now six such proteins linked to ALS (TDP43 $3^{100,101}$, FUS/TLS ${ }^{102,103}$, TAF15 104,105, EWSR $1^{106}$, hnRNPA2B $1^{107}$, hnRNPA $1^{107}$ ), with undoubtedly more to follow. (hnRNP refers to heterogeneous nuclear ribonucleoprotein, the class name for all these RNA binding proteins). The predicted prion-like regions of these proteins are distinct from the RNA Recognition Motif (RRM) regions, yet toxicity requires both ${ }^{108,109}$. Thus, it is unlikely that toxicity flows from the simple accumulation of poorly-digestible prion-like protein fragments in the cell.

Indeed, it is unlikely that the propensity of RNA binding proteins to 'misfold' has evolved by happenstance, and it has been suggested that RNA binding proteins co-aggregate physiologically in cytosolic mRNA processing bodies ( $\mathrm{P}$ bodies) and stress granules through their alternative conformational region ${ }^{110}$. Thus, the protein misfolding may not be an unfortunate evolutionary accident but rather a conserved function essential to normal protein homeostasis.

Familial ALS mutations occurring in the prion-like regions of RNA binding proteins serve to increase the propensity of these proteins to aggregate through their prion-like domains ${ }^{107,111}$. This may unduly stabilize stress granules and $\mathrm{P}$ bodies so that they no longer disaggregate when appropriate, progressively sequestering mRNAs and miRNAs and other RNA binding proteins in the cytosol to the detriment of normal mRNA processing. Conceptually, the presence of more than one RRM on the same RNA-binding protein (e.g. TDP43 has two ${ }^{99}$ ) might allow more complex aggregates to occur.

TDP43 and FUS/TLS at least are also mRNA transport proteins ${ }^{112}$, found in dendrites and axons ${ }^{113,114}$, and local protein synthesis could be impaired if these transport proteins were inappropriately retained in cytosolic aggregates. Interference with distal axonal protein production would be of particular interest in ALS given the susceptibility introduced by the length and activity of motor axons. Last, RNA binding proteins play essential roles in the nucleus (facilitating, inter alia, the splicing of pre mRNA) and toxicity could also flow from disrupted nuclear processing of mRNA ${ }^{115}$.

As one would expect, there are physiological controls on RNA binding proteins that serve to prevent pathological aggregation. In yeast, the parent mRNA of these proteins is present in low quantities, the translation efficiency is low, and the proteins themselves have short half-lives ${ }^{116}$. TDP43 at least controls its own expression level (in part by binding to and destabilizing its mRNA transcript ${ }^{117}$ ), and sequestration in disease states could increase translation and fuel cytosolic aggregation. In keeping with this, over-expressing human wildtype protein results in a dose-dependent reduction in endogenous mouse TDP43 mRNA $^{118}$. Beyond a certain threshold the tendency for peripheral accumulation of aggregates in a cell might increase, with aggregation-prone mutations reducing this threshold.

Exchange of cytosolic proteins from an involved neuron to a neighbour could spread disease aggregates in a prion-like fashion. (It has recently been reported that microparticles containing mRNA and associated proteins are present in human CSF, differ between brain-injured patients and controls, and differentially perturb RNA processing in stem cells in vitro ${ }^{119}$ ). This might explain the topographic spread of disease. Cytosolic mislocalization of wtTDP43 is seen in most sporadic ALS patients ${ }^{100}$, not just mTDP43 FALS, suggesting that disruption of RNA processing may be widely important.

\section{ii. The unfolded protein response and cellular stress}

Intercellular passage of prion-like proteins can occur in vitro, but it is unknown whether this process is important in vivo, and it is unclear that it would explain the temporal profile of ALS without invoking additional processes. Also, it would seem unlikely that cytosolic sequestration of a single or a few mRNA species could be solely responsible for disease expression. TDP43 binds to over 6000 mRNAs $^{115}$, and FUS a smaller number of seemingly different $\mathrm{mRNAs}^{120}$, yet mutations in either cause the same phenotype. A more general disruption of protein homeostasis seems likely, although the possibility of additional protein-specific effects remains. A wide-spread dysfunction of proteostasis related to a FALS mutation as above, or other processes as below, could trigger cellular stress responses, which are known to occur in ALS.

By way of background, damaged proteins and organelles are targeted for breakdown and recycling by the ubiquitinproteasome system (smaller and shorter-lived substrates) or autophagy (larger aggregates or organelles). However, protein homeostasis also requires general control of protein production that can respond to environmental factors such as the availability of nutrients, cell injury, or cell cycle state, and can direct cell growth, or cell division, or invoke conservative defense responses. These higher order controls are integrated with regulatory controls in the endoplasmic reticulum (ER) protein secretory pathways that are important in limiting protein misfolding (hence 'unfolded protein response' or UPR). However, the reach of the UPR may extend far beyond the ER, to non-secreted protein control, lipid and glucose metabolism, cell division, innate immunity, the induction of autophagy, and cellular de-differentiation and programmed cell death ${ }^{121}$. As expected, proteasomal function, autophagy, and the UPR are linked $^{122}$. 
The UPR is often over-simplified as having three arms, each capable of interacting with other pathways ${ }^{121}$. One arm involves the activation of the endonuclease inositol-requiring protein 1 (IRE1) leading to a splice excision in X-Box1 (XBP1) mRNA and expression of XBP1(s) genes, to increase among others chaperone proteins to assist in protein folding; one arm reduces the production of most other proteins presumably to offload the ER; and the third arm activates the (usually) pro-apoptotic translation factor ATF6, presumably reflecting at that point a degree of protein misfolding incompatible with cell survival. The response is contingent on the cell state, the three arms may act independently, and each may be cytoprotective or proapoptotic under different circumstances ${ }^{121}$.

The second arm of the UPR is particularly interesting. In eukaryotes, mRNA translation requires the initiation factor Eif $2 \alpha$. When the UPR is activated, specific kinases (in particular, 'PERK') phosphorylate Eif $2 \alpha$ and, in its phosphorylated state Eif $2 \alpha-\mathrm{P}$ is no longer able to initiate most protein translation. (Translation of those proteins needed to combat ER stress may proceed without need for Eif $2 \alpha$ initiation $^{123}$.) The generalized reduction in translation offloads the ER and allows proper protein folding to catch up.

An important study by Saxena ${ }^{69}$ in $\mathrm{mSOD}$ mice indicates how a UPR might arise on the background of a FALS mutation that has been present since conception, and contribute to disease. In motor neurons known to be affected early, there is an initial ubiquitin response and upregulation of cytosolic proteasomal function, then an abrupt down regulation of these processes and an almost ten-fold increase in the UPR, conjoined with a marked microglial expansion and activation, that occurs over a four week period just prior to clinical disease onset. In resistant motor neuron pools known to be affected later in ALS, a similar increase in the UPR is seen, later, just prior to their known involvement.

The cause of the sudden transition and UPR spike is unclear, as a priori one might have expected persisting proteosomal activity and a slow but steady rise in the UPR. Nonetheless, this spike in the UPR has a temporal profile which might be expected in ALS. Elevated levels of Eif $2 \alpha-\mathrm{P}$ are present in ALS ${ }^{124}$ suggesting that the UPR is operative in human disease.

\section{Prion-like aggregates and the UPR could be tightly linked}

Cytosolic mRNA aggregates and the UPR have been presented above as two related processes affecting proteostasis. In reality, a clear distinction between the two may not be possible. Sequestration of mRNAs and RNA binding proteins in abnormal aggregates will activate the UPR, and phosphorylated Eif $2 \alpha$ and non-translated mRNAs induced by the UPR are linked to the formation of stress granules ${ }^{125}$. Conceptually, pathological aggregates might afford a better explanation for cell-to-cell spread, while the UPR provides a better explanation for the terminal cell death and common disease phenotype seen in ALS.

\section{Disrupted proteostasis accommodates other features of ALS}

Disrupted proteostasis could provide an explanation for the intercellular spread of pathology and the common terminal disease phenotype and, in addition, accommodates several other known or presumed features of ALS. In particular, disrupted proteostasis can be potentiated or triggered by environmental influences and aging and could provide an explanation for the terminal inflammation, as follows.

\section{Disrupted proteostasis and environmental influences}

In transgenic mouse models of ALS it is necessary to express the human transgene at high copy number to produce disease. In humans with single copy FALS mutation (the usual state), disease is delayed for 40-60 years on average, but the variability in onset is large (20-80 years; Table 2) and the disease penetrance is incomplete over a normal human lifespan, perhaps because most fully penetrant mutations would be incompatible with survival. Environmental factors could provide a needed second hit, and presumably they are of greater importance in sporadic disease. (Even in 'sporadic' disease there may be undiscovered Mendelian mutations of low penetrance, de novo mutation or polygenic influences, and the distinction between familial and sporadic disease may not be clear-cut).

It has been known for several years that sciatic nerve injury in mSOD mice accelerates the disease course ${ }^{126}$. In the abovementioned study by Saxena ${ }^{69}$, the UPR is induced precociously by sciatic nerve crush, suggesting one mechanism whereby genetic and environmental influences interact at the level of protein homeostasis. A single sciatic crush leads to a reversible UPR, but repeated crushes are not reversible. Axotomy of retinal ganglion cells induces a UPR and cell death through apoptosis $^{127}$. As an anecdotal aside, perhaps like most ALS physicians, I have seen several patients whose disease followed temporally and spatially regenerative trauma to the same region, and in light of the above, such occurrences may not be coincidental.

Another environmental factor of potential importance is neurotrophic viral infection, which may induce a protective down-regulation of cellular mRNA translation to prevent viral spread, and viruses in turn have evolved ways to subvert usual cellular RNA responses as an adaptive mechanism ${ }^{128}$. For example, a role for exogenous or endogenous retroviruses in ALS has been suggested ${ }^{129-131}$.

Last, there is a long suspicion that ingested or inhaled neurotoxins could predispose to ALS, directly or through epigenetic change ${ }^{132}$. These include potentially excitotoxic or oxidative stressors. Oxidative, mitochondrial, or excitotoxic abnormalities are present in ALS, and are associated with the UPR and generalized stress responses ${ }^{124}$.

\section{Disrupted proteostasis and aging and maladaptive repair}

Age is by far the most significant risk factor for ALS, with risk increasing with age, although possibly declining somewhat in the elderly ${ }^{133}$. As pointed out many years ago, it is possible that the metabolic demands on a motor neuron increase as the size of the motor unit increases ${ }^{134}$, with ever-increasing oxidative stress. Age-related oxidative damage to mitochondria has long been linked to neurodegeneration ${ }^{135}$. As mentioned, oxidative, mitochondrial, and excitotoxic stress are associated with the UPR and generalized stress responses ${ }^{124}$. Also, for uncertain reasons autophagy declines with age ${ }^{122}$. These considerations tie increasing age to perturbed protein homeostasis. 
Some effects might have a more complex relation to age. As peripheral motor neurons malfunction with disease, axons may attempt to regenerate and neighbouring axons sprout into denervated endplate regions. If loss of regenerative potential were paramount, difficulty should increase with age; however over-exuberant axonal regeneration and sprouting could also be harmful under some circumstances but might be seen preferentially in younger adults. Adult mice over-expressing the neuronal growth-associated protein GAP43 have increased death of motor neurons in the spinal cord at the level of sciatic transection ${ }^{136}$, and doubly transgenic mice, over-expressing both mSOD1 and GAP43, have accelerated disease onset and terminal decline ${ }^{137}$. GAP43 levels are elevated in the spinal cord of ALS patients ${ }^{138}$. Also, the UPR may lead to cellular dedifferentiation $^{121}$ and excessive growth signals could induce diseased adult motor neurons to inappropriately re-enter the cellcycle, resulting in apoptosis ${ }^{139,140}$. Of relevance, the cyclindependent kinase Cdk4 is upregulated in mSOD mice ${ }^{141}$. It is presently unclear whether these influences might increase, decline, or remain unchanged with age.

\section{Disrupted proteostasis and inflammation}

In most circumstances, cellular stress responses are cytoprotective. From a teleological viewpoint, a survival advantage to the organism might be conferred if this response were relayed to neighbouring cells, perhaps explaining why the UPR is intimately linked to activation of the innate immune system $^{128}$. (For example, sciatic nerve crush activates a UPR in the motor neuron and also elicits an intense ipsilateral regional microglial response in the spinal $\operatorname{cord}^{69}$ ). In this way, the UPR may not be cell autonomous. An organismal response of the first arm of the UPR (XBP-1) has been identified in $C$ elegans ${ }^{142}$, but it is presently unknown whether this is true in human neurodegenerative disease.

Under certain circumstances, these immune responses may be maladaptive. In classical prion disease, terminal pathology requires microglial involvement ${ }^{143}$. The intense microglial reaction accompanying the symptomatic phases of ALS has been mentioned, as well as the transition from a neuroprotective to neurotoxic phenotype ${ }^{74}$. Given the essential interplay between motor neurons and glia in the pathogenesis of $\mathrm{ALS}^{63}$, it seems plausible that the death of some motor neurons could activate neighbouring glia and consequently increase the death rate of adjacent and previously-uninvolved motor neurons. Some of the many factors involved in the cross-talk between motor neurons and glia are known ${ }^{144}$ but further definition is required.

\section{Therapeutic considerations and future challenges}

In summary, ALS may be, at its core, a disease of disturbed proteostasis induced with greater likelihood in patients genetically predisposed, potentiated by age, possibly triggered by environmental insult, and worsened terminally by maladaptive inflammation (Figure 2). Protein homeostasis is a tightly-regulated and conserved process that may be difficult to

Figure 2. Disrupted RNA processing may be central to ALS pathophysiology. In health, heterogeneous nuclear ribonucleoproteins (hnRNPs) bind DNA and especially RNA and shuttle between the nucleus and the cytosol, where they facilitate pre-mRNA splicing and transport of mRNA from the nucleus to the cytosol and endoplasmic reticulum, and to axons and dendrites for local protein production. As part of general control of protein production, mRNA processing is occasionally paused and mRNAs, miRNAs and hnRNPs reversibly localize in cytosolic stress granules. mRNAs are recycled in processing $(P)$ bodies. Both processes require binding through essential prion-like domains on the hnRNPs. In disease, inappropriate stabilization of stress granules and $P$ bodies may occur, and may lead to the formation of cytosolic aggregates, sequestering mRNA, miRNA, and especially hnRNPs in the cytosol. Disease may then flow from a loss of nuclear and peripheral hnRNP function, and cellular aggregates may lead to disease spread from cell to cell through a prion-like process. Aggregates activate the protective unfolded protein response (UPR), one arm of which reduces general protein translation by phosphorylating a key initiation factor (EIF2 $\alpha$ ). However, prolonged activation may be harmful. The innate immune response is activated, and apoptosis occurs as a common terminal pathway. Mutations in hnRNPs inhibit their ability to disaggregate and are a cause of familial ALS. Oxidative stress, mitochondrial dysfunction and excitotoxicity potentiate the UPR, and increasing age impairs autophagy, which is the major route by which cellular aggregates are cleared.

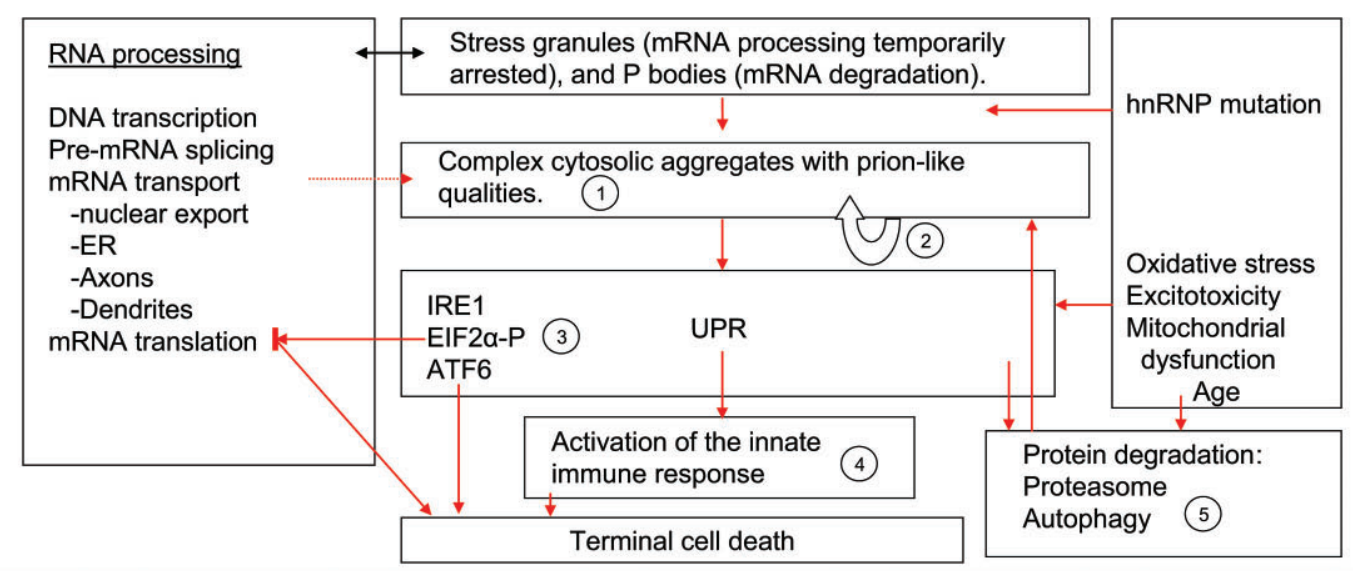

Future therapy could be directed at reducing aggregate stability (1), reducing cell-to-cell passage of prion-like particles (2), reducing maladaptive UPR (3), targeting inflammation (4), or increasing aggregate clearance (5).

Figure 2: Disrupted RNA processing may be central to ALS pathophysiology. 
therapeutically perturb. The focal nature of ALS complicates therapeutic considerations, as exposing all cells to a therapy for a vital function but directed at a small number of motor neurons will almost certainly fail.

mSOD mice haploinsufficient for PERK (reducing Eif $2 \alpha-\mathrm{P}$ ) have accelerated disease course ${ }^{145}$, and blocking Eif $2 \alpha-\mathrm{P}$ dephosphorylation in $\mathrm{mSOD}$ mice modestly prolongs disease onset $^{69}$. This suggests that reducing protein translation and unloading the ER may be helpful, and has raised the possibility of therapeutic intervention by interfering with Eif $2 \alpha-\mathrm{P}$ dephosphorylation.

Even ignoring the focal nature of ALS, this approach is unlikely to prove satisfactory. If a cell is subjected to prolonged stress and phosphorylation of Eif $2 \alpha$ is maintained, protein production is reduced, possibly accompanied by DNA methylation and reduced transcription ${ }^{146}$, cell viability is compromised, and the third arm of the UPR initiates apoptosis. Sustained activation of Eif $2 \alpha-\mathrm{P}$ has been shown to contribute to neuronal death in classical prion disease ${ }^{147}$, and sustained activation of Eif $2 \alpha-\mathrm{P}$ may be occurring in ALS as Eif $2 \alpha-\mathrm{P}$ levels are elevated in the spinal cord of ALS patients ${ }^{124}$. Indeed this irreversible phase may be a common terminal event in ALS motor neurons, further strengthening the conceptual link with classical prion disease.

Nonetheless, some aspects of disrupted proteostasis might be amenable to intervention, especially with better understanding of those triggers leading to an irreversible UPR and apoptosis. It will be important to elucidate the mechanisms underlying the above-mentioned sharp reduction in proteasomal function and concomitant induction of the UPR preceding motor neuron death $^{69}$, as there may be elements ${ }^{122}$ that do not implicate usual physiological proteostasis (and therefore might be more amenable to intervention). Destabilization of toxic aggregates would be a promising approach. Treatments aimed at inducing heat shock proteins, and facilitating autophagy, might be helpful in reducing the progression of prion-like disease ${ }^{148}$. Therapeutic drainage of CSF could reduce the intercellular passage of prionlike proteins. This has failed in Alzheimer's disease ${ }^{149}$, but could possibly show greater success in lower limb onset ALS.

Reducing the damage from deleterious inflammation remains a promising approach. Non-specific anti-inflammatory treatment has been unhelpful, but treatment might be more successful when targeting specifically factors linking the UPR to activation of the innate immune system (as correcting these might perturb normal cells to a lesser degree). Likewise, treatment of ALSassociated metabolic abnormalities harmful to motor neurons has been futile, but concomitant treatment might be beneficial once disturbed proteostasis is addressed. In dominant FALS, inactivation of the mutated allele could help stabilize the UPR and slow progression to an apoptotically-defined response.

In this context, attention must again be turned to the appropriateness of the mSOD mouse as a disease model, as it is likely that protein half-lives in pathological aggregates are similarly long in man and mouse, yet the clinical disease process in the mouse takes a little more than a month to run its course from start to finish. There may simply not be enough time for therapies to work in the mouse, especially if distal axonal mRNA translation is important.

\section{Conclusions}

There are plausible reasons to believe that ALS treatments to date have failed because we have targeted coincident or predisposing processes rather than those more fundamental to the progressive dysfunction and death of motor neurons. Processes central to motor neuron death may implicate aberrant proteostasis, involving cytosolic sequestration of mRNA, miRNA and RNA binding proteins, possible cell-to-cell spread of self-templating toxic aggregates, sustained UPR and terminally, a non-reversible transition to an apoptoticallydefined response. Once activated by whatever means, these mechanisms may be at least partially self-perpetrating and less dependent on the underlying trigger, explaining a common disease phenotype in sporadic disease and in all forms of FALS in spite of a variety of predisposing causes.

Depending on one's preference in disease classification, the ALS disease process (as distinct from the underlying predisposing condition) may best be considered distinct and in most patients relatively short.

Protein homeostasis is vital and conserved and interventions may be difficult. Nonetheless, at least some elements may be amenable to intervention. In unfavourable circumstances, we might turn a short bad disease into a long bad disease, while in favourable circumstances with better understanding and multiple interventions some forms of ALS may be treatable or even reversible. Early detection and early treatment would seem essential.

\section{ACKNOWLEDGEMENTS}

This paper evolved from a talk of the same title presented at the ALS BC symposium in Vancouver on November 15, 2012. The author thanks co-presenters Dr. Andy Eisen and Dr. John Ravits who offered constructive comments on an earlier version of the manuscript.

\section{REFERENCES}

1. Miller R, Bradley W, Cudkowicz M, et al. TCH346 Study Group. Phase II/III randomized trial of TCH346 in patients with ALS. Neurology. 2007;69(8):776-84.

2. Norris FH, Tan Y, Fallat RJ, Elias L. Trial of oral physostigmine in amyotrophic lateral sclerosis. Clin Pharmacol Ther. 1993;54(6): 680-2.

3. Askmark H, Aquilonius SM, Gillberg PG, et al. Functional and pharmacokinetic studies of tetrahydroaminoacridine in patients with amyotrophic lateral sclerosis. Acta Neurol Scand. 1990;82 (4):253-8.

4. Parton M, Mitsumoto H, Leigh PN. Amino acids for amyotrophic lateral sclerosis / motor neuron disease. Cochrane Database of Systematic Reviews 2008, Issue 2.

5. National Institute of Neurological Disorders and Stroke [homepage on the Internet]. NINDS Amyotrophic Lateral Sclerosis (ALS) Information Page. [Updated 2013 July 8; cited 2013 April 29]. Available from: Ninds.nih.gov/disorders/amyotrophiclateral sclerosis/ALS.htm

6. Gredal $\mathrm{O}$, Werdelin $\mathrm{L}, \mathrm{Bak} \mathrm{S}$, et al. A clinical trial of dextromethorphan in amyotrophic lateral sclerosis. Acta Neurol Scand. 1997;96(1):8-13

7. Miller RG, Moore DH 2nd, Gelinas DF, et al. Phase III randomized trial of gabapentin in patients with amyotrophic lateral sclerosis. Neurology. 2001;56(7):843-8.

8. Eisen A, Stewart H, Schulzer M, Cameron D. Anti-glutamate therapy in amyotrophic lateral sclerosis: a trial using lamotrigine. Can J Neurol Sci. 1993;20(4):297-301. 
9. Blin O, Pouget J, Aubrespy G, et al. A double-blind placebocontrolled trial of L-threonine in amyotrophic lateral sclerosis. J Neurol. 1992;239(2):79-81

10. de Carvalho M, Pinto S, Costa J, Evangelista T, Ohana B, Pinto A. A randomized, placebo-controlled trial of memantine for functional disability in amyotrophic lateral sclerosis. Amyotroph Lateral Scler. 2010;11(5):456-60.

11. Miller RG, Shepherd R, Dao H, et al. Controlled trial of nimodipine in amyotrophic lateral sclerosis. Neuromuscul Disord. 1996;6 (2):101-4.

12. Pascuzzi RM, Shefner J, Chappell AS, et al. A phase II trial of talampanel in subjects with amyotrophic lateral sclerosis. Amyotroph Lateral Scler. 2010 May 3;11(3):266-71.

13. Cudkowicz ME, Shefner JM, Schoenfeld DA, et al. A randomized, placebo-controlled trial of topiramate in amyotrophic lateral sclerosis. Neurology. 2003;61(4):456-64.

14. Di Lazzaro V, Pilato F, Profice P, et al. Motor cortex stimulation for ALS: a double blind placebo-controlled study. Neurosci Lett. 2009;464(1):18-21.

15. Miller RG, Smith SA, Murphy JR, et al. A clinical trial of verapamil in amyotrophic lateral sclerosis. Muscle Nerve. 1996;19(4): $511-15$.

16. Miller RG, Mitchell JD, Moore DH. Riluzole for amyotrophic lateral sclerosis (ALS)/motor neuron disease (MND). Cochrane Database of Systematic Reviews 2012, Issue 3. Art. No.: CD001447. DOI: 10.1002/14651858.CD001447.pub3.

17. Piepers S, Veldink JH, de Jong SW, et al. Randomized sequential trial of valproic acid in amyotrophic lateral sclerosis. Ann Neurol. 2009;66(2):227-34.

18. Kelemen J, Hedlund W, Orlin JB, Berkman EM, Munsat TL. Plasmapheresis with immunosuppression in amyotrophic lateral sclerosis. Arch Neurol. 1983;40(12):752-3.

19. Cudkowicz ME, Shefner JM, Schoenfeld DA, et al. Trial of celecoxib in amyotrophic lateral sclerosis. Ann Neurol. 2006; 60(1):22-31.

20. Smith SA, Miller RG, Murphy JR, Ringel SP. Treatment of ALS with high dose pulse cyclophosphamide. J Neurol Sci. 1994;124 Suppl:84-7.

21. Appel SH, Stewart SS, Appel V, et al. A double-blind study of the effectiveness of cyclosporine in amyotrophic lateral sclerosis. Arch Neurol. 1988;45(4):381-6.

22. Meininger V, Drory VE, Leigh PN, Ludolph A, Robberecht W, Silani V. Glatiramer acetate has no impact on disease progression in ALS at $40 \mathrm{mg} /$ day: a double-blind, randomized, multicentre, placebo-controlled trial. Amyotroph Lateral Scler. 2009;10(5-6): 378-83.

23. Mora JS, Munsat TL, Kao KP, et al. Intrathecal administration of natural human interferon alpha in amyotrophic lateral sclerosis. Neurology. 1986;36(8):1137-40.

24. Beghi $\mathrm{E}$, Chiò $\mathrm{A}$, Inghilleri $\mathrm{M}$, et al. A randomized controlled trial of recombinant interferon beta-1a in ALS. Italian Amyotrophic Lateral Sclerosis Study Group. Neurology. 2000;54(2):469-74.

25. Meucci N, Nobile-Orazio E, Scarlato G. Intravenous immunoglobulin therapy in amyotrophic lateral sclerosis. J Neurol. 1996;243(2):117-20.

26. Gordon PH, Moore DH, Miller RG, et al. Western ALS Study Group. Efficacy of minocycline in patients with amyotrophic lateral sclerosis: a phase III randomised trial. Lancet Neurol. 2007;6(12):1045-53.

27. Meininger V, Asselain B, Guillet P, et al; Pentoxifylline European Group. Pentoxifylline in ALS: a double-blind, randomized, multicenter, placebo-controlled trial. Neurology. 2006;66(1): 88-92.

28. Rivera VM, Grabois M, Deaton W, Breitbach W, Hines M. Modified snake venom in amyotrophic lateral sclerosis. Lack of clinical effectiveness. Arch Neurol. 1980;37(4):201-3.

29. Drachman DB, Chaudhry V, Cornblath D, et al. Trial of immunosuppression in amyotrophic lateral sclerosis using total lymphoid irradiation. Ann Neurol. 1994;35(2):142-50.

30. Zhang YJ, Zhang J, Zhang N, et al. The randomized open clinical trial on a novel free radical scavenger edaravone in amyotrophic lateral sclerosis. Chin J Contemp Neurol Neurosurg. [Internet]. 2007;7(2):161-4
31. Chiò A, Cucatto A, Terreni AA, Schiffer D. Reduced glutathione in amyotrophic lateral sclerosis: an open, crossover, randomized trial. Ital J Neurol Sci. 1998;19(6):363-6.

32. Louwerse ES, Weverling GJ, Bossuyt PM, Meyjes FE, de Jong JM. Randomized, double-blind, controlled trial of acetylcysteine in amyotrophic lateral sclerosis. Arch Neurol. 1995;52(6):559-64.

33. Lange DJ, Murphy PL, Diamond B, et al. Selegiline is ineffective in a collaborative double-blind, placebo-controlled trial for treatment of amyotrophic lateral sclerosis. Arch Neurol. 1998;55 (1):93-6.

34. Desnuelle C, Dib M, Garrel C, Favier A. A double-blind, placebocontrolled randomized clinical trial of alpha-tocopherol (vitamin E) in the treatment of amyotrophic lateral sclerosis. ALS riluzole-tocopherol Study Group. Amyotroph Lateral Scler Other Motor Neuron Disord. 2001;2(1):9-18.

35. Kwieciński H, Janik P, Jamrozik Z, Opuchlik A. [The effect of selegiline and vitamin $\mathrm{E}$ in the treatment of ALS: an open randomized clinical trials]. Neurol Neurochir Pol. 2001;35(1 Suppl):101-6.

36. Munsat TL, Easterday CS, Levy S, Wolff SM, Hiatt R. Amantadine and guanidine are ineffective in ALS. Neurology. 1981;31(8): 1054-5.

37. Norris FH Jr, Calanchini PR, Fallat RJ, Panchari S, Jewett B. The administration of guanidine in amyotrophic lateral sclerosis. Neurology. 1974;24(8):721-8.

38. Scelsa SN, MacGowan DJ, Mitsumoto H, et al. A pilot, doubleblind, placebo-controlled trial of indinavir in patients with ALS. Neurology. 2005;64(7):1298-300.

39. Fareed GC, Tyler HR. The use of isoprinosine in patients with amyotrophic lateral sclerosis. Neurology. 1971;21(9):937-40.

40. Olson WH, Simons JA, Halaas GW. Therapeutic trial of tilorone in ALS: lack of benefit in a double-blind, placebo-controlled study. Neurology. 1978;28(12):1293-5.

41. Aggarwal SP, Zinman L, Simpson E, et al; Northeast and Canadian Amyotrophic Lateral Sclerosis consortia. Safety and efficacy of lithium in combination with riluzole for treatment of amyotrophic lateral sclerosis: a randomised, double-blind, placebo-controlled trial. Lancet Neurol. 2010;9(5):481-8.

42. Chiò A, Borghero G, Calvo A, et al; LITALS Study Group. Lithium carbonate in amyotrophic lateral sclerosis: lack of efficacy in a dose-finding trial. Neurology. 2010;75(7):619-25.

43. Olarte MR, Gersten JC, Zabriskie J, Rowland LP. Transfer factor is ineffective in amyotrophic lateral sclerosis. Ann Neurol. 1979;5 (4):385-8.

44. Kaufmann P, Thompson JL, Levy G, et al; QALS Study Group. Phase II trial of CoQ10 for ALS finds insufficient evidence to justify phase III. Ann Neurol. 2009;66(2):235-44.

45. Pastula DM, Moore DH, Bedlack RS. Creatine for amyotrophic lateral sclerosis/motor neuron disease. Cochrane Database of Systematic Reviews 2012, Issue 12. Art. No.: CD005225. DOI: 10.1002/14651858.CD005225.pub3.

46. BiogenIdec.com [homepage on the Internet] News- Press Release Details 2013 Jan 3. [Updated 2013 Jan 3; cited 2013 Apr 29] Available from: http://www.biogenidec.com/press_release_ details.aspx?ID=5981\&ReqId=1770780

47. Trophos.com [homepage on the Internet] News- Press Release [Updated 2011 Dec 13; cited 2013 Apr 29]. Available from: http://www.trophos.com/news/pr20111213.htm

48. The BDNF Study Group (Phase III). A controlled trial of recombinant methionyl human BDNF in ALS. Neurology. 1999; 52(7):1427-33

49. Lacomblez L, Bouche P, Bensimon G, Meininger V. A doubleblind, placebo-controlled trial of high doses of gangliosides in amyotrophic lateral sclerosis. Neurology. 1989;39(12):1635-7.

50. Harrington H, Hallett M, Tyler HR. Ganglioside therapy for amyotrophic lateral sclerosis: a double-blind controlled trial. Neurology. 1984;34(8):1083-5.

51. Smith RA, Melmed S, Sherman B, Frane J, Munsat TL, Festoff BW. Recombinant growth hormone treatment of amyotrophic lateral sclerosis. Muscle Nerve. 1993;16(6):624-33.

52. Saccà $\mathrm{F}$, Quarantelli $\mathrm{M}$, Rinaldi $\mathrm{C}$, et al. A randomized controlled clinical trial of growth hormone in amyotrophic lateral sclerosis: 
clinical, neuroimaging, and hormonal results. J Neurol. 2012; 259(1): 132-8

53. Beauverd M, Mitchell JD, Wokke JHJ, Borasio GD. Recombinant human insulin-like growth factor I (rhIGF-I) for the treatment of amyotrophic lateral sclerosis/motor neuron disease. Cochrane Database of Systematic Reviews 2012, Issue 11. Art. No.: CD002064. DOI: 10.1002/14651858.CD002064.pub3.

54. Meininger V, Bensimon G, Bradley WR, et al. Efficacy and safety of xaliproden in amyotrophic lateral sclerosis: results of two phase III trials. Amyotroph Lateral Scler Other Motor Neuron Disord. 2004;5(2):107-17.

55. Bongioanni P, Reali C, Sogos V. Ciliary neurotrophic factor (CNTF) for amyotrophic lateral sclerosis or motor neuron disease. Cochrane Database of Systematic Reviews 2004, Issue 3. Art. No.: CD004302. DOI: 10.1002/14651858.CD004302. pub2.

56. Munsat TL, Taft J, Jackson IM, et al. Intrathecal thyrotropinreleasing hormone does not alter the progressive course of ALS: experience with an intrathecal drug delivery system. Neurology. 1992;42(5):1049-53

57. Aisen ML, Sevilla D, Edelstein L, Blass J. A double-blind placebocontrolled study of 3,4-diaminopyridine in amytrophic lateral sclerosis patients on a rehabilitation unit. J Neurol Sci. 1996;138 (1-2):93-6.

58. Mulder DW, Kurland LT, Offord KP, Beard CM. Familial adult motor neuron disease: amyotrophic lateral sclerosis. Neurology. 1986;36(4):511-7.

59. Rosen DR, Siddique T, Patterson D, et al. Mutations in $\mathrm{Cu} / \mathrm{Zn}$ superoxide dismutase gene are associated with familial amyotrophic lateral sclerosis. Nature. 1993;362(6415):59-62.

60. Lino MM, Schneider C, Caroni P. Accumulation of SOD1 mutants in postnatal motoneurons does not cause motoneuron pathology or motoneuron disease. J Neurosci. 2002;22(12):4825-32.

61. Wang L, Sharma K, Deng HX, et al. Restricted expression of mutant SOD1 in spinal motor neurons and interneurons induces motor neuron pathology. Neurobiol Dis. 2008;29(3):400-8.

62. Jaarsma D, Teuling E, Haasdijk ED, De Zeeuw CI, Hoogenraad CC. Neuron-specific expression of mutant superoxide dismutase is sufficient to induce amyotrophic lateral sclerosis in transgenic mice. J Neurosci. 2008;28(9):2075-88

63. Boillée S, Yamanaka K, Lobsiger CS, et al. Onset and progression in inherited ALS determined by motor neurons and microglia. Science. 2006;312(5778):1389-92.

64. Yamanaka K, Boillee S, Roberts EA, et al. Mutant SOD1 in cell types other than motor neurons and oligodendrocytes accelerates onset of disease in ALS mice. Proc Natl Acad Sci USA. 2008; 105(21):7594-9.

65. Yamanaka K, Chun SJ, Boillee S, et al. Astrocytes as determinants of disease progression in inherited amyotrophic lateral sclerosis. Nat Neurosci. 2008;11(3):251-3.

66. Lobsiger CS, Boillee S, McAlonis-Downes M, et al. Schwann cells expressing dismutase active mutant SOD1 unexpectedly slow disease progression in ALS mice. Proc Natl Acad Sci USA. 2009;106(11):4465-70.

67. Wang L, Pytel P, Feltri ML, Wrabetz L, Roos RP. Selective knockdown of mutant SOD1 in Schwann cells ameliorates disease in G85R mutant SOD1 transgenic mice. Neurobiol Dis. 2012;48(1):52-7.

68. Wong M, Martin LJ. Skeletal muscle-restricted expression of human SOD1 causes motor neuron degeneration in transgenic mice. Hum Mol Genet. 2010;1911):2284-302.

69. Saxena S, Cabuy E, Caroni P. A role for motoneuron subtypeselective ER stress in disease manifestations of FALS mice. Nat Neurosci. 2009;12(5):627-36.

70. Molofsky AV, Krencik R, Ullian EM, et al. Astrocytes and disease: a neurodevelopmental perspective. Genes Dev. 2012;26(9): 891-907.

71. Al-Chalabi A, Fang F, Hanby MF, et al. An estimate of amyotrophic lateral sclerosis heritability using twin data. J Neurol Neurosurg Psychiatry. 2010;81(12):1324-6.

72. Scott S, Kranz JE, Cole J, et al. Design, power, and interpretation of studies in the standard murine model of ALS. Amyotroph Lateral Scler. 2008;9(1):4-15.
73. Brooks BR. Natural history of ALS: symptoms, strength, pulmonary function, and disability. Neurology. 1996;47(4 Suppl 2):S71-81; discussion S81-2.

74. Liao B, Zhao W, Beers DR, Henkel JS, Appel SH. Transformation from a neuroprotective to a neurotoxic microglial phenotype in a mouse model of ALS. Exp Neurol. 2012;237(1):147-52.

75. Crosio C, Valle C, Casciati A, Iaccarino C, Carrì MT. Astroglial inhibition of NF- $x \mathrm{~B}$ does not ameliorate disease onset and progression in a mouse model for amyotrophic lateral sclerosis (ALS). PLoS One. 2011;6(3):e17187.

76. Lomen-Hoerth C. Amyotrophic lateral sclerosis from bench to bedside. Semin Neurol. 2008;28(2):205-11.

77. Gordon PH, Cheung YK, Levin B, et al; Combination Drug Selection Trial Study Group. A novel, efficient, randomized selection trial comparing combinations of drug therapy for ALS. Amyotroph Lateral Scler. 2008;9(4):212-22.

78. Lattante S, Conte A, Zollino M, et al. Contribution of major amyotrophic lateral sclerosis genes to the etiology of sporadic disease. Neurology. 2012;79(1):66-72.

79. Cudkowicz ME, McKenna-Yasek D, Sapp PE, et al. Epidemiology of mutations in superoxide dismutase in amyotrophic lateral sclerosis. Ann Neurol. 1997;41(2):210-21.

80. van Blitterswijk M, van Es MA, Hennekam EA, et al. Evidence for an oligogenic basis of amyotrophic lateral sclerosis. Hum Mol Genet. 2012;21(17):3776-84.

81. Alexander GM, Erwin KL, Byers N, et al. Effect of transgene copy number on survival in the G93A SOD1 transgenic mouse model of ALS. Brain Res Mol Brain Res. 2004;130(1-2):7-15.

82. Henriques A, Pitzer C, Schneider A. Characterization of a novel SOD-1(G93A) transgenic mouse line with very decelerated disease development. PLoS One. 2010;5(11):e15445.

83. Aggarwal A, Nicholson G. Normal complement of motor units in asymptomatic familial (SOD1 mutation) amyotrophic lateral sclerosis carriers. J Neurol Neurosurg Psychiatry. 2001;71(4): 478-81.

84. Aggarwal A, Nicholson G. Detection of preclinical motor neurone loss in SOD1 mutation carriers using motor unit number estimation. J Neurol Neurosurg Psychiatry. 2002;73(2):199-201.

85. Siddique T. Molecular genetics of familial amyotrophic lateral sclerosis. Adv Neurol. 1991;56:227-31.

86. Valdmanis PN, Daoud H, Dion PA, Rouleau GA. Recent advances in the genetics of amyotrophic lateral sclerosis. Curr Neurol Neurosci Rep. 2009;9(3):198-205.

87. Andersen PM, Al-Chalabi A. Clinical genetics of amyotrophic lateral sclerosis: what do we really know? Nat Rev Neurol. 2011; 7(11):603-15

88. Smith RA, Miller TM, Yamanaka K, et al. Antisense oligonucleotide therapy for neurodegenerative disease. J Clin Invest. 2006;116(8):2290-6.

89. Wang $\mathrm{H}$, Ghosh A, Baigude $\mathrm{H}$, et al. Therapeutic gene silencing delivered by a chemically modified small interfering RNA against mutant SOD1 slows amyotrophic lateral sclerosis progression. J Biol Chem. 2008;283(23):15845-52.

90. Urushitani M, Ezzi SA, Julien JP. Therapeutic effects of immunization with mutant superoxide dismutase in mice models of amyotrophic lateral sclerosis. Proc Natl Acad Sci USA. 2007; 104(7):2495-500.

91. Wang L, Grisotti G, Roos RP. Mutant SOD1 knockdown in all cell types ameliorates disease in G85R SOD1 mice with a limited additional effect over knockdown restricted to motor neurons. J Neurochem. 2010;113(1):166-74

92. Brown P, Gibbs CJ Jr, Rodgers-Johnson P, et al. Human spongiform encephalopathy: the National Institutes of Health series of 300 cases of experimentally transmitted disease. Ann Neurol. 1994; 35(5):513-29.

93. Fraser H, Behan W, Chree A, Crossland G, Behan P. Mouse inoculation studies reveal no transmissible agent in amyotrophic lateral sclerosis. Brain Pathol. 1996;6(2):89-99.

94. Chia R, Tattum MH, Jones S, Collinge J, Fisher EM, Jackson GS. Superoxide dismutase 1 and tgSOD1 mouse spinal cord seed fibrils, suggesting a propagative cell death mechanism in amyotrophic lateral sclerosis. PLoS One. 2010;5(5):e10627. 
95. Grad LI, Guest WC, Yanai A, et al. Intermolecular transmission of superoxide dismutase 1 misfolding in living cells. Proc Natl Acad Sci USA. 2011;108(39):16398-403.

96. Wang L, Deng HX, Grisotti G, Zhai H, Siddique T, Roos RP. Wildtype SOD1 overexpression accelerates disease onset of a G85R SOD1 mouse. Hum Mol Genet. 2009;18(9):1642-51.

97. Ralph GS, Radcliffe PA, Day DM, et al. Silencing mutant SOD1 using RNAi protects against neurodegeneration and extends survival in an ALS model. Nat Med. 2005;11(4):429-33.

98. Raoul C, Abbas-Terki T, Bensadoun JC, et al. Lentiviral-mediated silencing of SOD1 through RNA interference retards disease onset and progression in a mouse model of ALS. Nat Med. 2005; 11(4):423-8.

99. King OD, Gitler AD, Shorter J. The tip of the iceberg: RNA-binding proteins with prion-like domains in neurodegenerative disease. Brain Res. 2012;1462:61-80.

100. Neumann M, Sampathu DM, Kwong LK, et al. Ubiquitinated TDP43 in frontotemporal lobar degeneration and amyotrophic lateral sclerosis. Science. 2006;314(5796):130-3.

101. Arai T, Hasegawa M, Akiyama H, et al. TDP-43 is a component of ubiquitin-positive tau-negative inclusions in frontotemporal lobar degeneration and amyotrophic lateral sclerosis. Biochem Biophys Res Commun. 2006;351(3):602-11.

102. Kwiatkowski TJ Jr, Bosco DA, Leclerc AL, et al. Mutations in the FUS/TLS gene on chromosome 16 cause familial amyotrophic lateral sclerosis. Science. 2009;323(5918):1205-8.

103. Vance C, Rogelj B, Hortobágyi T, et al. Mutations in FUS, an RNA processing protein, cause familial amyotrophic lateral sclerosis type 6. Science. 2009;323(5918):1208-11.

104. Ticozzi N, Vance C, Leclerc AL, et al. Mutational analysis reveals the FUS homolog TAF15 as a candidate gene for familial amyotrophic lateral sclerosis. Am J Med Genet B Neuropsychiatr Genet. 2011;156B(3):285-90.

105. Couthouis J, Hart MP, Shorter J, et al. A yeast functional screen predicts new candidate ALS disease genes. Proc Natl Acad Sci USA. 2011;108(52):20881-90.

106. Couthouis J, Hart MP, Erion R, et al. Evaluating the role of the FUS/TLS-related gene EWSR1 in amyotrophic lateral sclerosis. Hum Mol Genet. 2012;21(13):2899-911.

107. Kim HJ, Kim NC, Wang YD, et al. Mutations in prion-like domains in hnRNPA2B1 and hnRNPA 1 cause multisystem proteinopathy and ALS. Nature. 2013 Mar 3. [Epub ahead of print].

108. Johnson BS, McCaffery JM, Lindquist S, Gitler AD. A yeast TDP43 proteinopathy model: Exploring the molecular determinants of TDP-43 aggregation and cellular toxicity. Proc Natl Acad Sci USA. 2008;105(17):6439-44.

109. Daigle JG, Lanson NA Jr, Smith RB, et al. RNA-binding ability of FUS regulates neurodegeneration, cytoplasmic mislocalization and incorporation into stress granules associated with FUS carrying ALS-linked mutations. Hum Mol Genet. 2013;22(6):1193-205.

110. Gilks N, Kedersha N, Ayodele M, et al. Stress granule assembly is mediated by prion-like aggregation of TIA-1. Mol Biol Cell. 2004;15(12):5383-98.

111. Johnson BS, Snead D, Lee JJ, McCaffery JM, Shorter J, Gitler AD. TDP-43 is intrinsically aggregation-prone, and amyotrophic lateral sclerosis-linked mutations accelerate aggregation and increase toxicity. J Biol Chem. 2009;284(30):20329-39.

112. Fujii R, Okabe $\mathrm{S}$, Urushido T, et al. The RNA binding protein TLS is translocated to dendritic spines by mGluR5 activation and regulates spine morphology. Curr Biol. 2005;15(6):587-93.

113. Kiebler MA, Bassell GJ. Neuronal RNA granules: movers and makers. Neuron. 2006;51(6):685-90.

114. Tolino M, Köhrmann M, Kiebler MA. RNA-binding proteins involved in RNA localization and their implications in neuronal diseases. Eur J Neurosci. 2012;35(12):1818-36.

115. Polymenidou M, Lagier-Tourenne C, Hutt KR, et al. Long premRNA depletion and RNA missplicing contribute to neuronal vulnerability from loss of TDP-43. Nat Neurosci. 2011;14(4): 459-68.

116. Gsponer J, Babu MM. Cellular strategies for regulating functional and nonfunctional protein aggregation. Cell Rep. 2012;2(5): 1425-37.
117. Ayala YM, De Conti L, Avendaño-Vázquez SE, et al. TDP-43 regulates its mRNA levels through a negative feedback loop. EMBO J. 2011;30(2):277-88

118. Xu YF, Gendron TF, Zhang YJ, et al. Wild-type human TDP-43 expression causes TDP-43 phosphorylation, mitochondrial aggregation, motor deficits, and early mortality in transgenic mice. J Neurosci. 2010;30(32):10851-9.

119. Patz S, Trattnig C, Grünbacher G, et al. More than cell dust: microparticles isolated from cerebrospinal fluid of brain injured patients are messengers carrying mRNAs, miRNAs and proteins. J Neurotrauma. 2013 Jan 29. [Epub ahead of print].

120. Colombrita C, Onesto E, Megiorni F, et al. TDP-43 and FUS RNAbinding proteins bind distinct sets of cytoplasmic messenger RNAs and differently regulate their post-transcriptional fate in motoneuron-like cells. J Biol Chem. 2012;287(19):15635-47.

121.Hetz C. The unfolded protein response: controlling cell fate decisions under ER stress and beyond. Nat Rev Mol Cell Biol. 2012;13(2):89-102.

122. Lilienbaum A. Relationship between the proteasomal system and autophagy. Int J Biochem Mol Biol. 2013;4(1):1-26.

123. Spriggs KA, Bushell M, Willis AE. Translational regulation of gene expression during conditions of cell stress. Mol Cell. 2010;40 (2):228-37.

124. Ilieva EV, Ayala V, Jové M, et al. Oxidative and endoplasmic reticulum stress interplay in sporadic amyotrophic lateral sclerosis. Brain. 2007;130(Pt12):3111-23.

125. Kedersha NL, Gupta M, Li W, Miller I, Anderson P. RNA-binding proteins TIA-1 and TIAR link the phosphorylation of eIF-2 alpha to the assembly of mammalian stress granules. J Cell Biol. 1999;147(7):1431-42

126. Sharp PS, Dick JR, Greensmith L. The effect of peripheral nerve injury on disease progression in the SOD1(G93A) mouse model of amyotrophic lateral sclerosis. Neuroscience. 2005;130(4): 897-910.

127. Hu Y, Park KK, Yang L, et al. Differential effects of unfolded protein response pathways on axon injury-induced death of retinal ganglion cells. Neuron. 2012;73(3):445-52.

128. Reineke LC, Lloyd RE. Diversion of stress granules and P-bodies during viral infection. Virology. 2013;436(2):255-67.

129. Silva MT, Leite AC, Alamy AH, et al. ALS syndrome in HTLV-I infection. Neurology. 2005;65(8):1332-3.

130. Silva MT, Harab RC, Leite AC, Schor D, Araújo A, Andrada-Serpa MJ. Human T lymphotropic virus type 1 (HTLV-1) proviral load in asymptomatic carriers, HTLV-1-associated myelopathy/ tropical spastic paraparesis, and other neurological abnormalities associated with HTLV-1 infection. Clin Infect Dis. 2007;44 (5):689-92.

131. Douville R, Liu J, Rothstein J, Nath A. Identification of active loci of a human endogenous retrovirus in neurons of patients with amyotrophic lateral sclerosis. Ann Neurol. 2011;69(1):141-51.

132. Dion PA, Daoud H, Rouleau GA. Genetics of motor neuron disorders: new insights into pathogenic mechanisms. Nat Rev Genet. 2009;10(11):769-82.

133. McGuire V, Longstreth WT Jr, Koepsell TD, van Belle G. Incidence of amyotrophic lateral sclerosis in three counties in western Washington state. Neurology. 1996;47(2):571-3.

134. McComas AJ. Neuromuscular function and disorders. London: Butterworths; 1977

135.Loeb LA, Wallace DC, Martin GM. The mitochondrial theory of aging and its relationship to reactive oxygen species damage and somatic mtDNA mutations. Proc Natl Acad Sci USA. 2005 Dec 27;102(52):18769-70.

136. Harding DI, Greensmith L, Mason M, Anderson PN, Vrbova G. Overexpression of GAP-43 induces prolonged sprouting and causes death of adult motoneurons. Eur J Neurosci. 1999;11: 2237-42.

137.Jiang F, Li WP, Turnbull J. Progression and survival in GAP43/SOD-1 double transgenic mice. Amyotroph Lateral Scler. 2004;5(S2):94-5.

138. Parhad IM, Oishi R, Clark AW. GAP-43 gene expression is increased in anterior horn cells of amyotrophic lateral sclerosis. Ann Neurol. 1992;31(6):593-7. 
139. Park DS, Levine B, Ferrari G, Greene LA. Cyclin dependent kinase inhibitors and dominant negative cyclin dependent kinase 4 and 6 promote survival of NGF-deprived sympathetic neurons. J Neurosci. 1997;17(23):8975-83.

140.Imai T, Tokunaga A, Yoshida T, et al. The neural RNA-binding protein Musashi1 translationally regulates mammalian numb gene expression by interacting with its mRNA. Mol Cell Biol. 2001;21(12):3888-900.

141. Nguyen MD, Boudreau M, Kriz J, Couillard-Després S, Kaplan DR, Julien JP. Cell cycle regulators in the neuronal death pathway of amyotrophic lateral sclerosis caused by mutant superoxide dismutase 1. J Neurosci. 2003;23(6):2131-40.

142. Sun J, Liu Y, Aballay A. Organismal regulation of XBP-1-mediated unfolded protein response during development and immune activation. EMBO Rep. 2012;13(9):855-60.

143. Giese A, Brown DR, Groschup MH, Feldmann C, Haist I, Kretzschmar HA. Role of microglia in neuronal cell death in prion disease. Brain Pathol. 1998;8(3):449-57.
144. Barbeito AG, Mesci P, Boillée S. Motor neuron-immune interactions: the vicious circle of ALS. J Neural Transm. 2010; 117(8):981-1000.

145. Wang L, Popko B, Roos RP. The unfolded protein response in familial amyotrophic lateral sclerosis. Hum Mol Genet. 2011; 20(5):1008-15.

146. Chestnut BA, Chang Q, Price A, Lesuisse C, Wong M, Martin LJ. Epigenetic regulation of motor neuron cell death through DNA methylation. J Neurosci. 2011;31(46):16619-36.

147. Moreno JA, Radford H, Peretti D, et al. Sustained translational repression by eIF $2 \alpha-\mathrm{P}$ mediates prion neurodegeneration. Nature. 2012;485(7399):507-11.

148. Brundin P, Melki R, Kopito R. Prion-like transmission of protein aggregates in neurodegenerative diseases. Nat Rev Mol Cell Biol. 2010 Apr;11(4):301-7.

149. Silverberg GD, Mayo M, Saul T, Fellmann J, Carvalho J, McGuire D. Continuous CSF drainage in AD: results of a double-blind, randomized, placebo-controlled study. Neurology. 2008;71(3): 202-9. 